\title{
New species of leaf-beetles (Chrysomelidae) from Arabia
}

\section{Новые виды мистоедов (Chrysomelidae) из Аравии}

\author{
L.N. Medvedev \\ М.H. Медведев
}

Institute for Problems of Ecology and Evolution, Russian Academy of Sciences, Leninsky prospect 33, Moscow 119071, Russia. Институт проблем экологии и эволюции РАН, Ленинский проспект 33, Москва 119071, Россия.

KEY WORDS: Chrysomelidae, Arabia, new species, keys.

КЛЮЧЕВЫЕ СЛОВА: Chrysomelidae, Аравия, новые виды, ключ.

ABSTRACT. 8 new species from Arabia: Lema omanica, Lema vanharteni, Pachybrachis pygidialis, Tituboea saudica, Bacteriaspis arabica, Medythia yemenica, Yemenaltica marginata, Platypria arabica spp.n. are described. Keys to Lema Fabricius, 1798 and Bacteriaspis Weise, 1905 are given.

РЕЗЮМЕ. Описывается 8 новых видов из Аравии: Lema omanica, Lema vanharteni, Pachybrachis pygidialis, Tituboea saudica, Bacteriaspis arabica, Medythia yemenica, Yemenaltica marginata, Platypria arabica spp.n. Приводятся ключи для Lema Fabricius, 1798 и Bacteriaspis Weise, 1905.

\section{Introduction}

Chrysomelidae of Arabia are still not very well studied, nevertheless the revision of group published 15 years ago [Medvedev, 1996]. In the last years I had a possibility to study additional materials from this area. Main material used for this publication, which was collected by Dr. Van Harten and fixed in alcohol (more than 600 ex.) I had received for my disposal a few years ago. Besides, small materials from different collections was also used. As a result, 11 new species are described, partly from a few genera firstly found in Arabia.

Next abbreviations are used for the depository places:

NHMB - Naturhistorisches Basel, Switzerland;

LM - author's collection, Moscow, Russia;

MD - M.Daccordi collection, Verona, Italy.

\section{Taxonomy}

\section{Lema (s.str) omanica sp.n.}

MATERIAL. Holotype (sex not determined): Oman, Dhofar, Wadi Darbat, $17^{\circ} 04^{\prime} 50^{\prime \prime N}, 54^{\circ} 25^{\prime} 80^{\prime}$ E, 9.IX.2000, leg. D. Gianasso (LM).

Paratype: Socotra, Dirhushus, leg. Wranik, 1 ex. (LM).

DESCRIPTION. Fulvous with more or less darkened apical segments of antennae, elytra black with more or less dark fulvous epipleurae.

Head impunctate, vertex triangular, convex, distinctly delimited from occiput, with deep contral groove in posterior half. Antennae reach a little bhind humerous, proportions of segments are as $12-5-7-7-14-12-12-11-10-10-12$, preapical segments about twice as long as wide. Prothorax 1.2 times as wide as long, strongly constricted in middle, surface impunctate, with deep transverse impression before base. Scutellum trapeziform, finely punctate. Elytra 1.8 times as long as wide, without postbasal impression, scutellar row with 5-6 punctures, interspaces narrow, flat, only on apical slope more or less costate. Metapleurae pubescent. Length of body $5.2-5.4 \mathrm{~mm}$.

DIAGNOSIS. A species in question is a typical representative of $L$. pauperata group and have to be placed near L. risoriae Lacordaire 1845 because of entirely black elytra, but differs well with more short antennae and absence of postbasal impression on elytra.

\section{Lema (s.str.) vanharteni sp.n.}

Figs 1-4

MATERIAL. Holotype (sex not determined): Yemen, $12 \mathrm{~km}$ NW of Manakhah, tree-nursery, 24.VI.-4.VIII.2003, Malaise trap, leg. Van Harten (LM).

Paratypes: same locality and date, $10 \mathrm{ex}$ (LM); same locality, 15.V.-24.VI.2003, 1 ex. (LM); same locality, 15.IX.-22.X.2003, 3 ex. (LM); Oman, Dhofar region, Ain Razat, 2.X.2001, 110 m., leg. M. Dellacasa, 2 ex. (PM); Oman, Dhofar region, Hajaf dint, 27.VIII.2000-2980 ft, leg. M. Dellacasa, 1 ex. (PM); Oman, Dhofar region, Hajaf dint, 27.IX.2001, 900 m., leg. M. Dellacasa, 1 ex. (PM).

DESCRIPTION. Head red fulvous with labrum and anterior part of clypeus black or dark metallic, antennae blackish blue, but sometimes with one or two basal segments fulvous. Prothorax red fulvous, often with metallic sheen, rarely with extreme base metallic green, scutellum metallic or reddish, elytra red fulvous, usually with broad sutural metallic green stripe, which is very variable, sometimes occupying most part of surface, rarely strongly reduced (Figs 1-4). Underside and legs metallic blue with sides of abdomen and sometimes tibiae and tarsi reddish to fulvous.

Body elongate with parallel-sided elytra. Head strongly punctate and pubescent, frontal triangle as long as wide, delimited on sides with deep grooves, divided in middle with deep impression, except anterior third; vertex almost perpendicular to frons, but without distinct transverse ridge or elevation between frons and vertex. Proportions of antennal segments are as 10-5-10-10-13-11-11-11-10-9-11, preapical segments subquadrate, as long as wide. Prothorax 1.2 times as wide as long, constricted just behind middle, distinctly punctate, with basal transverse groove and impression 
on each side of middle. Scutellum subquadrate with rounded apex, pubescent. Elytra 1.7-1.8 times as long as wide, without clear postbasal impression, with closely placed rows of deep punctures, interspaces narrow, costate on apical slope. Metasternum pubescent with bare stripe inside of metepimera. Length of body $6.3-7.0 \mathrm{~mm}$.

DIAGNOSIS. This species belongs to L. tibialis group and is near L. cephalotes Lacordaire, 1845 from North Africa, but differs well in distinct metallic colour of underside and legs, bicolor elytra and smaller size.

Only one species of this genus was included in a key of Arabian Chrysomelidae [Medvedev, 1996]. To the moment 6 species are recorded for this region, so a key to Arabian species of Lema is proposed.

1(4) Head and prothorax impunctate. Labrum fulvous. Metapleurae pubescent

2(3) Body entirely fulvous. Length 5.4-5.8 $\mathrm{mm}$.

L. pauperata Lacordaire

3(2) Body fulvous with black elytra, antennae black or piceous with fulvous basal segments. Length $5.2-5.4 \mathrm{~mm}$. L.omanica Medvedev, sp.n.

4(1) Head and prothorax distinctly punctate. Labrum black.

5(10) Frons almost perpendicular to vertex (an angle about $90-100^{\circ}$ ), tubercles of frontal triangle not convex. Preapical antennal segments subquadrate or feebly elongate.

6(9) Upperside entirely fulvous, sometimes with feeble metallic sheen. Frons divided from vertex with transverse ridge-like elevation. Metapleurae glabrous.

7(8). Frons divided from vertex with produced anteriorly and ridge-like elevation. Tibiae fulvous or at least much paler than femora. Underside usually black with abdomen at least partly fulvous, but sometimes underside entirely fulvous L. tibialis Laporte

8(7) Frons divided from vertex with feeble and not produced anteriorly elevation. Underside black with feeble metallic sheen. Legs black fore tibiae might be fulvous on apices Lema cephalotes Lacordaire

9(6) Elytra bicolor, fulvous with variable metallic green sutural stripe (Figs 1-4). Head without distinct transverse elevation between frons and vertex. Underside metallic green with fulvous sides of abdomen. Metapleurae pubescent ............................. L. vanharteni Medvedev, sp.n.

10(5) Frons arcuately prolonged to vertex, tubercles of frontal triangle convex. Preapical antennal segments distinctly elongate elongate, especially segment 5 . Body without metallic color. Elytra fulvous, sometimes with preapical black spot. Metapleurae glabrous L. fuscitarsis Jacoby.
Tituboea saudica Medvedev, sp.n.

Fig. 6

MATERIAL. Holotype ( $\left(0^{7}\right)$ : Saudi Arabia, $12 \mathrm{~km} \mathrm{S.} \mathrm{Khaybar,}$ 680 m, 26.IV.1979 (LM)

DESCRIPTION.Fulvous with prothorax a little more reddish, apical antennal segments, 2 small round spots behind middle of elytra and sides of metasternum black.

Body parallel-sided, twice as long as wide. Head punctate and sparsely pubescent, clypeus practically impunctate and bare, arcuately emarginated on anterior margin, frons and vertex longitudinally impressed in middle. Antennae strongly serrate from the $5^{\text {th }}$ segment, segment 4 triangular, but very small.

Prothorax twice as wide as long, slightly narrowed anteriorly, with rounded side margins and elevated posterior angles, surface shining, sparsely punctate. Scutellum triangular. Elytra 1.5 times as long as wide, with feeble epipleural lobe, strongly and densely punctate. Anterior legs not elongated, with tarsi thin and a little shorter than tibiae, proportions of tarsal segments are as 10-8-6-9 (without claws), the first segment twice as long as wide. Aedeagus with acute triangular apex, without any impressions on underside, feebly curved in lateral view (Fig. 6). Length of body $3.3 \mathrm{~mm}$.

DIAGNOSIS. This is the smallest species among Arabian Tituboea. It is nearest to T.filitarsis Lacordaire, 1848, having also not elongated anterior tarsi of male, but differs immediately in form of aedeagus; $T$. filitarsis has distinctly curved aedeagus with obtuse triangular apex and a pair of impressions on underside before apex (Fig. 7).

\section{Pachybrachis pygidialis Medvedev, sp.n.}

MATERIAL. Holotype ( + ): Saudi Arabia, Thymama Park, 83 $\mathrm{km} \mathrm{N}$ of Riyadh, 600 m, 6.IV.1985, on Rhanterium epapossum, leg. H. Kessler (MD).

DESCRIPTION. Body fulvous with more dark punctures, especially on elytra; head with longitudinal stripe and two spots above antennae dark brown, metasternum and venter dark brown to black with sides of venter and apical sternite fulvous. Apices of antennae and claw segments of tarsi dark brown.

Head densely punctate, with longitudinal groove on frons, a distance between upper lobes of eyes about 1.4 times of distance between antennal insertions. Antennae thin and long, segment 3 a little shorter than 4, apical segments slightly thickened.

Prothorax 1.5 times as wide as long, broadest before base, distinctly narrowed anteriorly, with side margins almost

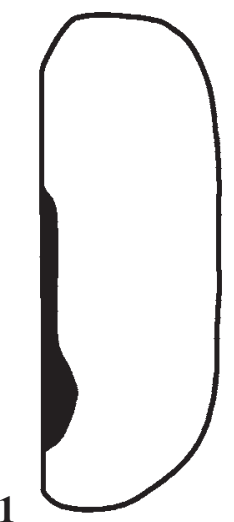

\section{2}

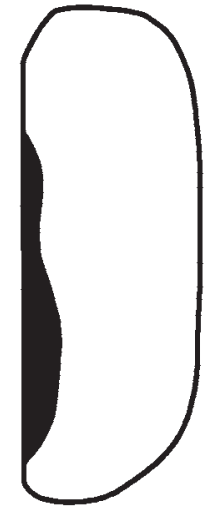

3

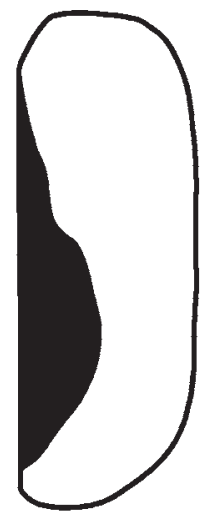

4
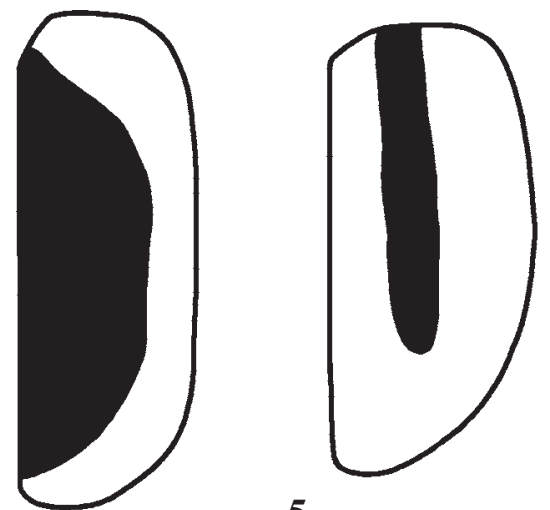

5

Figs 1-5. Elytron pattern: 1-4 - Lema vanharteni sp.n.; 5 - Medythia yemenica sp.n.

Рис. 1-5. Рисунок надкрылий: 1-4 - Lema vanharteni sp.n.; 5 - Medythia yemenica sp.n. 
straight, basal margin feebly biemarginate and narrowly emarginate. Surface strongly and densely punctate except narrow smooth stripe along anterior and posterior margins. Scutellum trapeziform, feebly transverse, impunctate. Elytra 1.3 times as long as wide, with sides parallel, surface with dense strong punctures, arranged laterally and in apical half in regular rows; interspaces costate on sides and flat on rest surface. Epipleurae with a row of punctures. Pygidium deeply triangularly emarginate on apex, postpygidium feebly notched on apex. Anterior femora distinctly more thick than middle and hind ones. Length of body $3.6 \mathrm{~mm}$, width $1.9 \mathrm{~mm}$.

DIAGNOSIS. This species is characteristic because of unusual structure of pygidium. The same character is known only for $P$. excisus Weise 1897 from Syria, but the latter species has well developed black pattern of upperside, narrow frons, confused elytral punctures and black pygidium with two flavous spots. The new species is very near morphologically and in colouration to P. glycyrrhizae Olivier 1808 from Transcaucasus and Near East, which has also regular rows of punctures on elytra, but pygidium only slightly notched.

The only known arabian species, $P$. saudicus Lopatin, 1979 differs immediately with entire pygidium, other colouration and confused elytral punctures.

\section{Bacteriaspis arabica Medvedev, sp.n.}

Fig. 8

MATERIAL. Holotype ( $\left.0^{7}\right)$ : North Yemen, Sana, 4.XI.1931, leg. N. Filippov (LM). This African genus is firstly recorded for Arabia.

DESCRIPTION. Fulvous, elytra with rather large, but poorly delimited preapical pitchy spot, apex of abdomen darkened.

Body elongate. Head impunctate, frontal tubercles triangular, delimited behind with straight line. Antennae short, reach anterior quarter of elytra, proportions of segments are as 5-3-5-6-6-5-5-5-5-5-6, preapical segments about twice as long as wide. Prothorax 1.45 times as wide as long, broadest just behind anterior angles, with protuberanse on hind margin covering scutellum; surface impunctate. Elytra 1.7 times as long as wide, finely and closely punctate, with microsculptured interspaces; there is deep groove at base near scutellum delimited on innerside with sharp ridge, on outerside with blunt tubercle. 5th abdominal sternite with deep groove at base and with large quadrangular median lobe. Aedeagus - Fig. 8. Length $4.5 \mathrm{~mm}$.

DIAGNOSIS. This is the third species of the genus, two other are known from east Africa. They differ as follows:

1(4) Elytra black in apical half $\left(\sigma^{7} \sigma^{7}\right)$ or entirely black (우).

2(3) Antennae fulvous with darkened apical segments. Prothorax impunctate. Length 4.0-4.8 mm. Lake Rudolf. .

B. pygmaeus Laboissiere 1921

3(2) Antennae black except basal segments. Prothorax punctate. Length 6.0-7.0 mm. Lake Nyassa.

B. scutellata (Baly 1878)

4(1) Elytra of male fulvous with poorly delimited dark preapical spot. Antennae fulvous, prothorax impunctate. Length $4.5 \mathrm{~mm}$. B. arabica Medvedev, sp.n.

\section{Medythia yemenica Medvedev, sp.n.}

Figs 5, 9

MATERIAL. Holotype ( $\left(^{7}\right)$ : Yemen, Ta'izz, VI.2002, on light, leg. Van Harten (LM).

DESCRIPTION. Fulvous, each elytron with black central stripe from base to apical quarter (Fig. 5).

Body elongate ovate. Head impunctate, frontal tubercles rounded, convex, well delimited, vertex with central impressed line. Antennae almost reach middle of elytra, proportions of segments are as 10-5-6-6-7-6-6-6-6-6-8, preapical segments about twice as long as wide. Prothorax a1.2 times as wide as long, with thickened anterior angles and rounded side margins, surface shining, distinctly punctate. Scutellum semicircular. Elytra 1.5 times as long as wide, not broadened posteriorly, surface shining, with dense punctures, which are a little larger than on prothorax. Spur of hind tibia short. Segment 1 of hind tarsus as long as the next segments combined. Aedeagus gradually narrowed to obtuse apex (Fig. 9). Length of body $3.0 \mathrm{~mm}$.
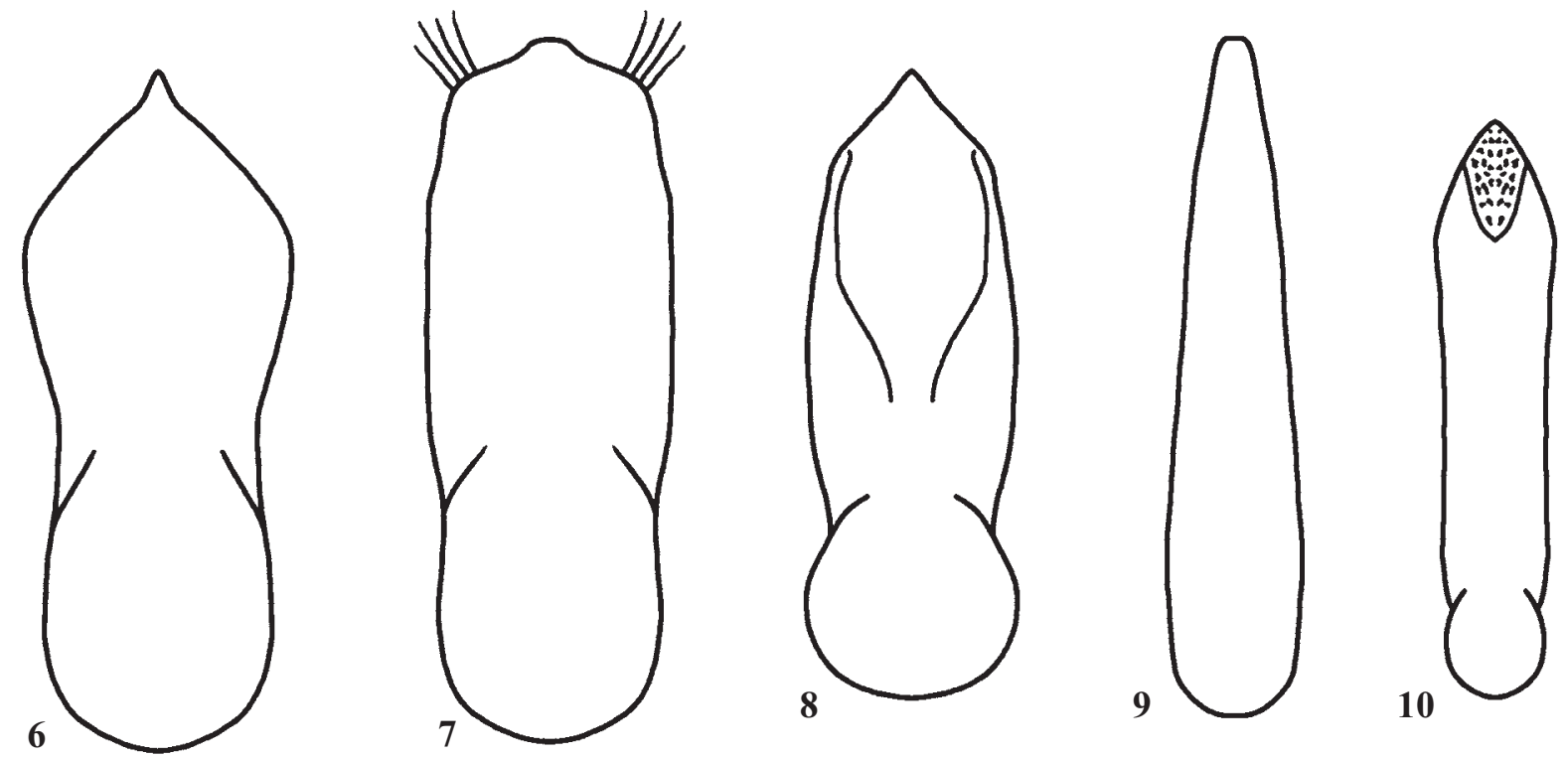

Figs 6-10. Aedeagus ventral: 6-Tituboea saudica sp.n.; 7-Tituboea filitarsis; 8 - Bacteriaspis arabica sp.n.; 9 -Medythia yemenica sp.n.; 10 - Yemenaltica marginata sp.n.

Рис. 6-10. Эдеагус, снизу: 6 - Tituboea saudica sp.n.; 7 - Tituboea filitarsis; 8 - Bacteriaspis arabica sp.n.; 9 - Medythia yemenica sp.n.; 10 - Yemenaltica marginata sp.n. 
DIAGNOSIS. Resembles in general appearance and elytral pattern M. punctatissima Berti, 1983, but differs with fulvous head, antennae and legs; differs well from all African species [Berti, 1983] in form of aedeagus, not having an elongate apical process. From M. quaterna (Fairmaire, 1880) differs, except form of aedeagus, also with fulvous lateral margin of elytra.

\section{Yemenaltica marginata Medvedev, sp.n.} Fig. 10

MATERIAL. Holotype ( $\left(^{7}\right)$ : Yemen, Ar Rujum (W Sana'a), 16.X.2000-15.I.2001, Malaise trap, 1900 m, leg. Van Harten (LM)

Paratype: Yemen, Ar Rujum (W Sana'a), 15.I.-IX.04.2002, Malaise trap, leg. Van Harten, 1 ㅇ (LM)

DESCRIPTION. Head and prothorax reddish fulvous, antennae piceous with 4 basal segments fulvous, scutellum black, elytra pale fulvous with dark piceous narrow lateral margin, more broad sutural stripe and apex, underside black, legs fulvous with apices of hind femora black, at least above.

Body narrow, elongate. Head microsculptured and very finely punctate, frontal tubercles large, flat, subquadrangular, shining and impunctate. Antennae reach middle of elytra, proportions of segments are as 12-6-6-7-7-7-7-7-7-7-9, preapical segments about twice as long as wide. Prothorax 1.7 times as wide as long, side margins straight, surface microsculptured, finely and densely punctuate, slightly impressed near hind angles. Scutellum semicircular, shining, impunctate. Elytra parallel-sided, 1.75 times as long as wide, surface microsculptured, with dense and practically confused punctures. Aedeagus narrow, with acute apex, almost straight in lateral view, underside with central ridge, bifurcate before apex (Fig. 10). Length of male $1.6 \mathrm{~mm}$, of female $1.8 \mathrm{~mm}$.

DIAGNOSIS. Differs well from Y. scorteccii Scherer, 1985 , a single species of the genus, with practically confused elytral punctures and dark piceous margins of elytra.

\section{Platypria (Dihirispa) arabica Medvedev, sp.n.} Fig. 11

MATERIAL. Holotype (sex not determined): Yemen, Sana'a, XII.1990, leg. Van Harten (LM). This genus is firstly recorded for Arabia.

DESCRIPTION. Fulvous, prothorax with black V-like spot before scutellum, 4 small round spots near each hind angle and apices of long spines, elytra with black dorsal spines and tubercles, lateral spines of anterior lobe and posterolateral area.

General appearance as in $P$. decemspinosa Kraatz, 1895. Prothorax with 4 long and 2 short spines, long spines thin. Lateral spines of elytra: 2 short on humerus, 5 long on anterior lobe, 1 very short and 2 long on median excavation, 3 moderately long on posterolateral area, 5 short on apical margin, anterior lobe with two rows of transparent windows; inner row with 5 windows on right side and only 4 on left side; outer row with 3 small round windows (Fig. 11). Win-

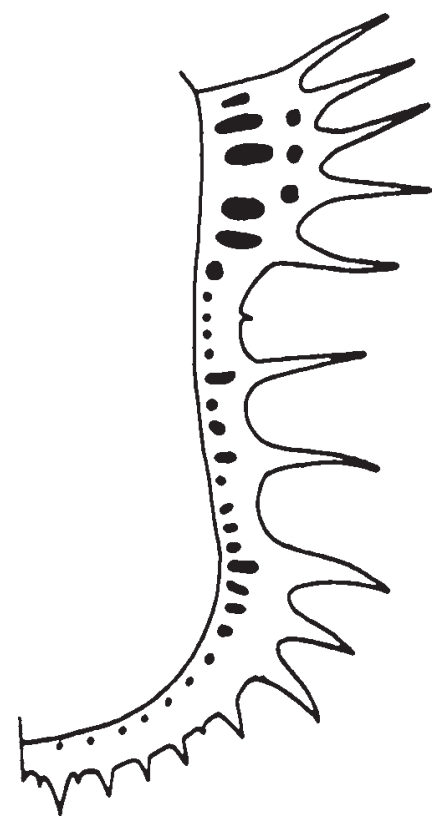

Fig. 11. Platypria arabica sp.n., lateral margin of elytron. Рис. 11. Platypria arabica sp.n., боковой край надкрылья.

dows on medial excavation rather large and subquadrate, on lateroapical part narrow and elongate, on apical margin small and round. Dorsal spines and tubercles have a formule: II $1^{* *}, 2,3^{*}, 4^{* *}, 5^{*}$, IV $2^{* *}, 3^{* *}, 4,5^{* *}$, VI $2,4^{*}$, VIII $3^{* *}$, $4^{* *}, 5^{*}$ [see Würmli, 1977]. Length of body $7.0 \mathrm{~mm}$.

DIAGNOSIS. Very alike at $P$. decemspinosa, but spines of prothorax narrow, windows on median excavation of elytra large and subquadrate, on lateroapical area sharply transverse. Elytral dorsal sculpture formule of $P$. decemspinosa is: II $1^{* *}, 2,3^{*}, 4^{*}, 5^{*}$, IV $2^{* *}, 3^{* *}, 4,5^{*}$, VI $2,4^{* *}$, YIII $3 * *, 4 * *, 5$ [Würmli, 1977]. Besides, latter species is abundant in West and Central Africa and in South Sudan, but absent in Northeast Africa.

\section{References}

Berti N. 1983. Les Medythia afrotropicaux et malgaches. Description de deux espèces nouvelles (Coleoptera, Chrysomelidae, Galerucinae) // Revue française d'Entomologie. N.S. T.5. No.3. P.95-100.

Medvedev L.N. 1996. The Chrysomelidae of Arabia // Fauna of Saudi Arabia. Vol.15. P.211-263.

Würmli M. 1977. Revision der Gattung Platypria: Die Arten der aethiopischen Region (Untergattung Dichirispa) // Revue Zoologique Africain. T.91. Fasc.4. P.955-973. 